\title{
Knowledge of lactational amenorrhea as a contraceptive method among mothers of infants aged 0-6 months in a district, Eastern Turkey
}

\author{
Edibe Pirincci $^{1}$, Rabia Taşdemir ${ }^{2}$, Ayse Ferdane Oguzoncul ${ }^{1}$
}

\author{
${ }^{1}$ Department of Public Health, School of Medicine, University of Firat, 23 119, Elazig, Turkey \\ ${ }^{2}$ Bigadic Director of the State Hospital 10440, Balikesir, Turkey
}

Received: 20 April 2016

Accepted: 14 May 2016

\author{
*Correspondence: \\ Dr. Edibe Pirincci, \\ E-mail: edibepirincci@yahoo.com
}

Copyright: (c) the author(s), publisher and licensee Medip Academy. This is an open-access article distributed under the terms of the Creative Commons Attribution Non-Commercial License, which permits unrestricted non-commercial use, distribution, and reproduction in any medium, provided the original work is properly cited.

\begin{abstract}
Background: Lactation is a natural defense against pregnancy. As long as a mother is nursing, she is delaying the return of fertility. This study aimed at evaluating the state of knowledge, among mothers of infants aged 0-6 months, on lactational amenorrhea as a contraceptive method, as well as these women's breastfeeding habits.

Methods: In this descriptive study 646 mothers were included. A questionnaire was used to interview one-on-one the mothers of infants aged 0-6 months, who had consented to such an interview. The data were evaluated by using the SPSS program; percentage, mean, and chi-square analyses were used.

Results: To the question: Does lactating protect you from pregnancy? $82.5 \%$ answered in the negative. While $28.6 \%$ of the subjects who had received family planning counseling postpartum had answered "yes" to this question, in subjects who had not received such counseling this proportion was $14.9 \%(\mathrm{p}=0.001)$. Those who had first done so within half an hour from delivery made up $81.4 \%$ of the sample. The proportion of those who had not yet resumed menstruations was $62.3 \%$. All of the mothers who had not resumed menstruating were still nursing; $99.2 \%$ were breastfeeding also at night.

Conclusions: A rural area of Turkey, the use of LAM as a contraceptive method remains low, even though the breastfeeding ratio is high.
\end{abstract}

Keywords: Breastfeeding, Lactational amenorrhea, Family planning, Turkey

\section{INTRODUCTION}

Lactation is a natural defense against pregnancy. As long as a mother is nursing, she is delaying the return of fertility. The natural mechanism triggered by breastfeeding interrupts ovulation and the menstrual cycle. According to family planning researchers, breastfeeding, as a traditional method to increase the interval between births, provides protection from pregnancy to a larger number of women than all other contraceptive methods. ${ }^{1}$ Many investigations of the efficacy of lactational amenorrhea method (LAM) have shown that this is an efficient and reliable method when specific criteria are met. ${ }^{2-4}$ Three criteria define LAM: a) feeding exclusively or almost exclusively with mother's milk; b) postpartum amenorrhea; c) infant younger than six months. The risk of pregnancy in the first six months for a breastfeeding mother who meets the LAM criteria is $2 \%{ }^{5,6}$ Women breastfeeding for longer than 6 months post-partum should initiate other modern methods of contraception to avoid unplanned pregnancy irrespective of breastfeeding style or menstrual status ${ }^{7}$.

The World Health Organization (WHO) recommends starting breastfeeding as soon as possible following delivery. ${ }^{8}$ Even though breastfeeding is a natural event, most mothers feel the need of reliable counseling and family and support. Therefore, in addition to pediatricians and obstetricians, mother-child health center personnel as well as physicians and nurses working in primary care should be knowledgeable on breastfeeding, its benefits, its contraceptive use and its techniques. ${ }^{9}$ This study aimed 
at evaluating the state of knowledge, among mothers of infants aged 0-6 months, on lactational amenorrhea as a contraceptive method, as well as these women's breastfeeding habits.

\section{METHODS}

This descriptive study performed in the Dogubeyazit district of the province of Agri, all public health care stations were visited in order to prepare a list of families with infants aged 0-6 months. Agri is an eastern Turkish city. In Dogubeyazit; the study population consisted in all 0-6 months old children, 1454 in total.

The sample including $50 \%$ of the population was selected by simple randomization, 727 infants' mothers being candidates for the study. Of these, 636 could be reached since participation was voluntary, resulting in the study participation rate of $87.5 \%$. The researchers prepared the questionnaire by reviewing the literature. The comprehensibility of questionnaire was verified by a pilot test with 15 infants' mothers who were not included in the research and was revised accordingly. The surveys were administered in face-to-face interview by trained pollsters in their homes. The data were analyzed using the SPSS program. The statistical analysis used percentages, means and chi-square tests depending on the quality of the variables. Means include their standard deviations and $\mathrm{p}<0.05$ was used as the threshold of significance.

\section{RESULTS}

The average age of the mothers in the study was 27.48 ( $\mathrm{SD}=5.59$ )years, (min:17, max:50) years; $45.9 \%$ were illiterate or barely literate and $43.1 \%$ had completed primary school, while $18.4 \%$ of the fathers were illiterate or barely literate and $56.8 \%$ had finished elementary school.

Table 1: Distribution of demographic characteristics of the mothers interviewed.

\begin{tabular}{|c|c|c|}
\hline Characteristics & Number & Percentage \\
\hline \multicolumn{3}{|l|}{ Age groups (years) } \\
\hline$\leq 19$ & 34 & 5.3 \\
\hline $20-29$ & 426 & 67.0 \\
\hline $30-39$ & 148 & 23.3 \\
\hline$\geq 40$ & 28 & 4.4 \\
\hline \multicolumn{3}{|l|}{ Mother's education level } \\
\hline Illiterate-literate & 292 & 45.9 \\
\hline Primary school & 274 & 43.1 \\
\hline High school-university & 70 & 11.0 \\
\hline \multicolumn{3}{|c|}{ Mother's occupation/work status } \\
\hline Working & 593 & 93.2 \\
\hline Not working (Housewife) & 43 & 6.8 \\
\hline \multicolumn{3}{|l|}{ Father's education level } \\
\hline Illiterate-literate & 117 & 18.4 \\
\hline Primary school & 361 & 56.8 \\
\hline High school-university & 158 & 24.8 \\
\hline \multicolumn{3}{|l|}{ Monthly income* } \\
\hline$\leq 500 \mathrm{TL}$ & 315 & 49.5 \\
\hline $501-1000 \mathrm{TL}$ & 256 & 40.3 \\
\hline $1001-2000 \mathrm{TL}$ & 52 & 8.2 \\
\hline $2001 \geq$ & 13 & 2.0 \\
\hline \multicolumn{3}{|l|}{ Mode of delivery } \\
\hline Normal delivery & 581 & 91.4 \\
\hline Caesarean section & 55 & 8.6 \\
\hline
\end{tabular}

The mothers were homemakers in $93.2 \%$ of the cases; $49.5 \%$ had a monthly income under 500 Turkish Liras (Table 1). The average age of the babies was 3.41 $(\mathrm{SD}=1.53)$ months. The $17.5 \%$ of mothers in the study stated that mother's milk protects from pregnancy. When those mothers answering Mother's milk protects from pregnancy were asked under which conditions does mother milk protect from pregnancy?, $0.7 \%$ answered only if feeding is exclusively with mother's milk and $16.8 \%$ as long as breastfeeding is continued. While there 
was no significant difference $(\mathrm{p}>0.05)$ with regard to age, occupational status, number of live children, place of birth or monthly income among subjects who believed that lactation protects from pregnancy and those who did not, educational status and postpartum counseling did make a statistically significant difference $(\mathrm{p}<0.05)$ (Table 2).

Table 2: Distribution of the answers to the question: "does breastfeeding protect from pregnancy?" according to some of the subject characteristics.

\begin{tabular}{|c|c|c|c|c|c|}
\hline \multirow{3}{*}{ Characteristics } & \multicolumn{5}{|c|}{ To provide protection against pregnancy breastfeeding } \\
\hline & \multicolumn{2}{|c|}{ Yes } & \multicolumn{2}{|c|}{ No } & \multirow[b]{2}{*}{ P-value } \\
\hline & $\mathrm{n}$ & $\%$ & $\mathrm{n}$ & $\%$ & \\
\hline \multicolumn{5}{|l|}{ Age groups (years) } & \multirow{5}{*}{$\begin{array}{l}\chi^{2}=0.87 \\
p=0.83\end{array}$} \\
\hline$\leq 19$ & 5 & 14.7 & 29 & 85.3 & \\
\hline $20-29$ & 73 & 17.1 & 353 & 82.9 & \\
\hline $30-39$ & 29 & 19.6 & 119 & 80.4 & \\
\hline$\geq 40$ & 4 & 14.3 & 24 & 85.7 & \\
\hline \multicolumn{5}{|l|}{ Mother's education level } & \multirow{4}{*}{$\begin{array}{l}\chi^{2}=6.37 \\
p=0.04\end{array}$} \\
\hline Illiterate-literate & 63 & 21.6 & 229 & 78.4 & \\
\hline Primary school & 38 & 13.9 & 236 & 86.1 & \\
\hline High school-university & 10 & 14.3 & 60 & 85.7 & \\
\hline \multicolumn{5}{|c|}{ Mother's occupation/work status } & \multirow{3}{*}{$\mathrm{p}=0.20 * *$} \\
\hline Working & 106 & 17.9 & 487 & 82.1 & \\
\hline Not working (Housewife) & 5 & 11.6 & 38 & 88.4 & \\
\hline \multicolumn{5}{|l|}{ Number of live children } & \multirow{4}{*}{$\begin{array}{l}\chi^{2}=4.58 \\
p=0.10\end{array}$} \\
\hline 1 & 29 & 15.6 & 157 & 84.4 & \\
\hline 2 & 31 & 14.5 & 183 & 85.5 & \\
\hline$\geq 3$ & 51 & 21.6 & 185 & 78.4 & \\
\hline \multicolumn{5}{|c|}{ Postpartum Menstruation Status } & \multirow{3}{*}{$\mathrm{p}=0.45^{* *}$} \\
\hline Menstruating & 38 & 15.8 & 202 & 84.2 & \\
\hline Amenorrhea & 73 & 18.4 & 323 & 81.6 & \\
\hline \multicolumn{5}{|c|}{ Postpartum family planning counseling } & \multirow{3}{*}{$\mathrm{p}=0.001 * *$} \\
\hline Received & 34 & 28.6 & 85 & 71.4 & \\
\hline Not received & 77 & 14.9 & 440 & 85.1 & \\
\hline \multicolumn{5}{|l|}{ Site of delivery } & \multirow{3}{*}{$\mathrm{p}=0.21 * *$} \\
\hline Home & 24 & 21.8 & 86 & 78.2 & \\
\hline Health care facility & 87 & 16.5 & 439 & 83.5 & \\
\hline \multicolumn{5}{|l|}{ Monthly income * } & \multirow{4}{*}{$\begin{array}{l}\chi^{2}=0.56 \\
p=0.75\end{array}$} \\
\hline$\leq 1000 \mathrm{TL}$ & 98 & 17.2 & 473 & 82.8 & \\
\hline $1001-2000 \mathrm{TL}$ & 11 & 21.2 & 41 & 78.8 & \\
\hline$\geq 2001 \mathrm{TL}$ & 2 & 15.4 & 11 & 84.6 & \\
\hline
\end{tabular}

*\$1=1.9 TL(Turkish Lira), **Fisher's Exact Test

The proportion of subjects who had not resumed menstruations among subjects who had been informed postpartum about breastfeeding was $72.8 \%$, compared to $55.1 \%$ for those who had not $(\mathrm{p}<0.0001)$. All the mothers had suckled their infants after birth, $81.4 \%$ had started within half an hour from delivery and $99.2 \%$ gave breast at night. Babies were weaned from mother's milk by $0.6 \%$ of subjects, the reason being expressed as "I had not enough milk". The proportion of subjects who had not resumed menstruations yet was $62.3 \%$. Among those who fed supplementary food to their children, $20.8 \%$ had not resumed menstruating, compared to $64.2 \%$ of those who used breastfeeding only. No statistically significant correlation was detected between menstrual status on the one hand and the first feeding after birth, feeding at every demand by the infant or the average interval among feedings $(\mathrm{p}>0.05)$ (Table 3$)$. 
Table 3: Distribution of breastfeeding data for the study subjects (mothers of infants aged 0-6 months).

\begin{tabular}{|c|c|c|c|c|c|}
\hline \multirow[t]{2}{*}{ Breastfeeding data } & \multicolumn{2}{|c|}{ Menses resume } & \multicolumn{3}{|c|}{ Continuing amenorrhea } \\
\hline & \multicolumn{2}{|c|}{ Number \% } & Number & $\%$ & P-value \\
\hline \multicolumn{6}{|c|}{ Received information on lactation from health care personnel? $(n=636)$} \\
\hline Yes & 70 & 27.2 & 187 & 72.8 & \\
\hline No & 170 & 44.9 & 209 & 55.1 & \\
\hline \multicolumn{6}{|c|}{ Interval from birth to first suckling $(n=636)$} \\
\hline $0-30$ minutes & 196 & 37.8 & 322 & 62.2 & \multirow{3}{*}{$\begin{array}{c}\chi^{2}=0.019 \\
p=0.99\end{array}$} \\
\hline 31-60 minutes & 30 & 37.0 & 51 & 63.0 & \\
\hline 61 minutes & 14 & 37.8 & 23 & 62.2 & \\
\hline \multicolumn{5}{|c|}{ Is the infant breastfed at every request? $(n=632)^{*}$} & \multirow{3}{*}{$\mathrm{p}>0.05^{* *}$} \\
\hline Evet & 231 & 37.6 & 384 & 62.4 & \\
\hline Hayır & 5 & 29.4 & 12 & 70.6 & \\
\hline \multicolumn{6}{|c|}{ Is the infant breast fed at night? $(\mathrm{n}=632)^{*}$} \\
\hline Yes & 233 & 37.2 & 394 & 62.8 & \multirow[t]{2}{*}{$* * *$} \\
\hline No & 3 & 60.0 & 2 & 40.0 & \\
\hline \multicolumn{5}{|c|}{ How long does the infant suckle a single breast at one time?(n=632)* } & \multirow{3}{*}{$\mathrm{p}>0.05^{* *}$} \\
\hline Less than 4 minutes & 171 & 38.6 & 272 & 61.4 & \\
\hline Longer than 4 minutes & 65 & 34.4 & 124 & 65.6 & \\
\hline \multicolumn{5}{|c|}{ Do you feed the baby any other food than mother's milk? $(\mathrm{n}=632)^{*}$} & \multirow{3}{*}{$\mathrm{p}<0.0001 * *$} \\
\hline Yes & 19 & 79.2 & 5 & 20.8 & \\
\hline No & 217 & 35.7 & 391 & 64.2 & \\
\hline
\end{tabular}

While working women among the mothers used some method of birth control, this proportion among homemakers was $35.4 \% \quad(\mathrm{p}<0.05)$. The use of contraception after delivery was correlated with the mothers' age, their educational status, number of live children, monthly income and the fact of having received postpartum family planning counseling or not $(\mathrm{p}<0.05)$, while no significance could be determined for the fathers' educational status or the postpartum resumption of menstruation ( $\mathrm{p}>0.05)$ (Table 4).

In answer to the question regarding which method they believed was the most effective in the breastfeeding period, $41.5 \%$ of subjects indicated intrauterine devices (IUD), $23.7 \%$ condoms, $11.6 \%$ withdrawal, $8.6 \%$ (55) LAM, $6.3 \%$ (40) birth control pills, $4.4 \%$ (28) tubal ligation and $3.1 \%$ (20) injectable contraception; 4 (0.8\%) expressed no opinion (Table 5).

A proportion of $36.5 \%$ of all subjects had started postpartum contraception; the remaining 63.5 did not use any protective method (Table 6). Of those who did, $10.7 \%$ preferred condoms, $9.7 \%$ LAM $8.5 \%$ withdrawal; the fourth most used method was IUD.

\section{DISCUSSION}

Breastfeeding plays an important role in the suppression of ovulation. In the process are protected from pregnancy. When asked the question does breastfeeding protect from pregnancy? $82.5 \%$ of subjects answered in the negative. When asked why they gave this answer, $54.1 \%$ ) said that they did not trust the method and $28.4 \%$ that they had heard that it did not protect. In a study reported that almost $52 \%$ of the women were unaware of the contraceptive effect of lactation for $25.7 \%$ who were knowledgeable about it. ${ }^{10}$ In the publication by LopezMartinezet $\mathrm{MG}$ et al the main reason given for not accepting LAM for purposes of contraception was a lack of trust in the method for $62.2 \%$. Our results are consistent with these. ${ }^{11}$

The proportion of mothers with low educational status answering yes to the question: does breastfeeding protect from pregnancy? was significantly higher than in those with high educational status $(p<0.05)$. While $28.6 \%$ of the subjects who had received family planning counseling postpartum had answered "yes" to this question, in subjects who had not received such counseling this proportion was $14,9 \%(\mathrm{p}=0.001)$. 
The rate of use of this method was found to be high among women who were given family planning education in the early postpartum and followed up for two years, as reported in a study performed in Russia. ${ }^{12}$ Studies performed in the UK and the USA have also shown that postpartum family planning education positively influences the women's decision about the use of the method. ${ }^{13,14} \mathrm{~A}$ multi-center study conducted in developing countries showed high contraception use among women receiving postpartum family planning counseling. ${ }^{15}$ These results are consistent with our findings. One of the factors influencing the adequacy of family planning services is the timeliness of counseling. The prenatal, perinatal and postpartum periods are not only those when women receive the most health care service but also those in which they are most open to receive family planning counseling. Of the subjects in our study, $82.7 \%$ had delivered in a health care facility. The proportion of those who received family planning counseling was $18,7 \%$, a very low percentage.

Table 4: Distribution of the use of contraception according to some subject characteristics.

\begin{tabular}{|c|c|c|c|c|c|}
\hline \multirow{3}{*}{ Characteristics } & \multicolumn{5}{|c|}{ Contraception method in the first six months following delivery } \\
\hline & \multirow{2}{*}{$\begin{array}{l}\text { Users } \\
\text { n }\end{array}$} & & \multicolumn{2}{|c|}{ Non-users } & \multirow[b]{2}{*}{ P-value } \\
\hline & & $\%$ & $\mathbf{n}$ & $\%$ & \\
\hline \multicolumn{6}{|l|}{ Age groups (years) } \\
\hline$\leq 19$ & 15 & 44.1 & 19 & 55.9 & \multirow{4}{*}{$\begin{array}{l}\chi^{2}=10.37 \\
p=0.01\end{array}$} \\
\hline $20-29$ & 138 & 32.4 & 288 & 67.6 & \\
\hline $30-39$ & 64 & 43.2 & 84 & 56.8 & \\
\hline$\geq 40$ & 15 & 53.6 & 13 & 46.4 & \\
\hline \multicolumn{5}{|l|}{ Mother's education level } & \multirow{4}{*}{$\begin{array}{l}\chi^{2}=10.77 \\
p=0.005\end{array}$} \\
\hline Illiterate-literate & 108 & 37.0 & 184 & 63.0 & \\
\hline Primary school & 87 & 31.8 & 187 & 68.2 & \\
\hline High school-university & 37 & 52.9 & 33 & 47.1 & \\
\hline \multicolumn{5}{|l|}{ Father's education level } & \multirow{4}{*}{$\begin{array}{l}\chi^{2}=0.12 \\
p=0.93\end{array}$} \\
\hline Illiterate-literate & 41 & 35.0 & 76 & 65.0 & \\
\hline Primary school & 133 & 36.8 & 228 & 63.2 & \\
\hline High school-university & 58 & 36.7 & 100 & 63.3 & \\
\hline \multicolumn{5}{|c|}{ Mother's occupation/work status } & \multirow{3}{*}{$\mathrm{p}=0.03 * *$} \\
\hline Working & 22 & 51.2 & 21 & 48.8 & \\
\hline Not working (Housewife) & 210 & 35.4 & 383 & 64.6 & \\
\hline \multicolumn{5}{|l|}{ Number of live children } & \multirow{4}{*}{$\begin{array}{l}\chi^{2}=7.73 \\
p=0.02\end{array}$} \\
\hline 1 & 70 & 37.6 & 116 & 62.4 & \\
\hline 2 & 63 & 29.4 & 151 & 70.6 & \\
\hline$\geq 3$ & 99 & 41.9 & 137 & 58.1 & \\
\hline \multicolumn{5}{|c|}{ Postpartum menstruation status } & \multirow{3}{*}{$\mathrm{p}=0.10^{* *}$} \\
\hline Menstruating & 78 & 32.5 & 162 & 67.5 & \\
\hline Amenorrhea & 154 & 38.9 & 242 & 61.1 & \\
\hline \multicolumn{5}{|c|}{ Postpartum family planning counseling } & \multirow{3}{*}{$\mathrm{p}=0.0001 * *$} \\
\hline Received & 90 & 75.6 & 29 & 24.4 & \\
\hline Not received & 142 & 27.5 & 375 & 72.5 & \\
\hline \multicolumn{5}{|l|}{ Site of delivery } & \multirow{3}{*}{$\mathrm{p}=0.0001 * *$} \\
\hline Home & 195 & 33.6 & 386 & 66.4 & \\
\hline Health care facility & 37 & 67.3 & 18 & 32.7 & \\
\hline \multicolumn{5}{|c|}{ Do you feed the baby any other food than mother's milk? } & \multirow{3}{*}{$\mathrm{p}=0.0001 * *$} \\
\hline Yes & 22 & 81.5 & 5 & 18.5 & \\
\hline No & 210 & 34.5 & 399 & 65.5 & \\
\hline \multicolumn{5}{|l|}{ Monthly income* } & \multirow{4}{*}{$\begin{array}{l}\chi^{2}=17.88 \\
p=0.0001\end{array}$} \\
\hline$\leq 1000 \mathrm{TL}$ & 193 & 33.8 & 378 & 66.2 & \\
\hline $1001-2000 \mathrm{TL}$ & 30 & 57.7 & 22 & 42.3 & \\
\hline$\geq 2001 \mathrm{TL}$ & 9 & 69.2 & 4 & 30.8 & \\
\hline Total & 232 & 36.5 & 404 & 63.5 & \\
\hline
\end{tabular}

*\$1=1.9 TL(Turkish Lira), **Fisher's Exact Test. 
Table 5: Distribution of the contraceptive method found to be most reliable by the subjects, all mothers of 0-6 month-old infants.

\begin{tabular}{|c|c|c|}
\hline $\begin{array}{l}\text { The contraceptive method found to be most reliable by the subjects, all mothers } \\
\text { of 0-6 month-old infants }\end{array}$ & $\mathbf{n}$ & $\%$ \\
\hline IUDs & 264 & 41.5 \\
\hline Condoms & 151 & 23.7 \\
\hline Withdrawal & 74 & 11.6 \\
\hline Lactationalamenorrhoea method & 55 & 8.6 \\
\hline Oral contraceptives & 40 & 6.3 \\
\hline Tubal ligation & 28 & 4.4 \\
\hline Injectables & 20 & 3.1 \\
\hline No opinion & 4 & 0.8 \\
\hline
\end{tabular}

This finding indicates that family planning was not effective. The rate of agreement with the statement that breastfeeding protects from pregnancy, among those subjects who had received family planning counseling, was $28.6 \%$. A study conducted in the Philippines showed insufficient knowledge about LAM of the part of family planning service providers in a situation in which $16 \%$ only of women to whom LAM had been suggested by a large majority of these same service providers. ${ }^{16}$

Table 6: Use of contraceptive methods by amenorrheic and nonamenorrheic, all mothers of 0-6 month-old infants.

\begin{tabular}{|c|c|c|c|c|c|c|}
\hline \multirow[b]{2}{*}{ Methods } & \multicolumn{2}{|c|}{ Not amenorrheic } & \multicolumn{2}{|c|}{ Amenorrheic } & \multicolumn{2}{|c|}{ Total } \\
\hline & $\mathbf{n}$ & $\%$ & $\mathbf{n}$ & $\%$ & $\mathbf{n}$ & $\%$ \\
\hline Not use any protective method & 162 & 40.1 & 242 & 59.9 & 404 & 63.5 \\
\hline Condoms & 26 & 38.2 & 42 & 61.8 & 68 & 10.7 \\
\hline Lactational amenorrhoea method & 14 & 22.6 & 48 & 77.4 & 62 & 9.7 \\
\hline Withdrawal & 17 & 31.5 & 37 & 68.5 & 54 & 8.5 \\
\hline IUDs & 10 & 38.5 & 16 & 61.5 & 26 & 4.1 \\
\hline Oral contraceptives & 7 & 50.0 & 7 & 50.0 & 14 & 2.2 \\
\hline Tubal ligation & 2 & 50.0 & 2 & 50.0 & 4 & 0.6 \\
\hline Injectables & 2 & 50.0 & 2 & 50.0 & 4 & 0.6 \\
\hline Total & 240 & 37.7 & 396 & 62.3 & 636 & 100.0 \\
\hline
\end{tabular}

Therefore an insufficiency both in the numbers of subjects receiving family planning counseling and, in parallel with the Philippines study, in the adoption of the method may be present in our study.

This should make it appropriate re-examine the service providers' knowledge level. One of the criteria for the efficacy of breastfeeding as a family planning method is the absence of menstruation in the mother. ${ }^{17}$ In present study, $37.7 \%$ of women was menstruating. Of these, $72.1 \%$ had already resumed menstruating for 1-2 months. This also indicates that the women did not see breastfeeding as an effective method. Mother's milk is the ideal food for infants aged 0-6 months, appropriate for their growth and development and superior to all other foods. Even though the habit of initial breastfeeding is widespread in our country, early intake of food supplements is a major problem. ${ }^{18}$
All the mothers in our study did suckle their newborn after delivery, $81.4 \%$ doing so within half an hour. At the time of study, 4 subjects $(0.6 \%)$ had weaned their infants from breast feeding, while $3.8 \%$ had started supplementing breast milk with other foods. One of the most important factors of lactational amenorrhea is the duration of suckling.

To prevent a new pregnancy, suckling must last 65 minutes or longer daily, while each episode of suckling must be of 4 minutes at least. ${ }^{19}$ When examining the suckling in our study, we see that $97.3 \%$ of the subjects fed their infant on every demand and that the suckling period for a single breast was four minutes or longer in $29.9 \%$ of cases. Taylor HW et al, report in their study that women suckled for a total of 180 minutes daily in the first three months, becoming progressively shorter. ${ }^{3}$ As for Tommaselli GA et al they indicated the presence of a considerable difference between the first quarter and the 
sixth month in breastfeeding time, which totaled 192 minutes on the average. ${ }^{2}$ While suckling frequency in our study was good, the feeding time was short. This could also suggest that the women were insufficiently knowledgeable in this matter.

While the rate of exclusively breastfeeding and amenorrhea, at the same time, was $55.3 \%$ among mothers who had work outside their home, it increased to $64.9 \%$ for homemakers. The respective rates in the study by Valdes V et al were $28.2 \%$ and almost 50\%. ${ }^{4}$ Amenorrhea among women who feed their infants exclusively with their milk is higher than in those who combine it with supplementary foods $(\mathrm{p}<0.0001)$. Informing mothers about lactation and its effects is highly significant for increasing the acceptance of LAM as a contraceptive method.

In our study, the contraceptive methods favored by the mothers of 0-6 month-old infants as being most trustworthy were, in the order of preference, the IUD, the condoms and withdrawal. LAM was trusted as a reliable contraceptive method by $8.6 \%$ of the subjects. A study conducted in Egypt showed a reliance on lactation as a contraceptive method in $4.0 \%$. Susu B et al. ${ }^{20}$ also reported that only $17 \%$ of women who used traditional methods relied on LAM. What all this suggests to us is that LAM as a contraceptive method may find acceptance among women, provided that an educational program about the method is implemented.

When asked about the family planning method they are using postpartum, $63.5 \%$ of the mothers answered that they were not using any. Of those women who did not use protection, $0.9 \%$ expressed the wish to become pregnant again. As for those who were using any method, the order of preference was condoms, LAM and withdrawal. The contraceptive method judged reliable by the mothers before delivery is different than the one used postpartum. Several studies determined that most couples did not adopt a modern contraceptive method but relied on amenorrhea resulting from lactation in this period as being efficient and safe., ${ }^{21,22}$ According to the results of the Turkey demographic and health survey (TNSA) 2008, $73 \%$ of married women use some contraceptive method, modern in $46 \%$ and $27 \%$ traditional in character. The most used of the modern methods is UTI, followed by condoms, while the most favored among traditional methods is withdrawal. ${ }^{23}$

Even though the use of contraception among our study subjects was not high, the high proportion of users of withdrawal, a traditional method, leads to believe that the success wished for family planning services has not been achieved. It is therefore particularly important for the health care personnel of antenatal service units and delivery clinics, in order to increase the use of efficient contraception, to provide a standard of family planning information complemented, if need be, by individual counseling. The LAM user proportion among the illiterate and barely literate women in our study was $12 \%$ while among the high school and university graduates it amounted to $4.3 \%$; the contraceptive use of lactation moved inversely to the educational level. A study by Khella AK et al showed that $52 \%$ of illiterate women used breastfeeding as a contraceptive method; versus. $35 \%$ of the ones with higher education. ${ }^{24}$ Our study is consistent in this with Khella AK et al's report.

\section{CONCLUSION}

In Dogubeyazit, a rural area of Turkey, the use of LAM as a contraceptive method remains low, even though the breastfeeding ratio is high. Our study findings also indicate that the subjects used lactation with contraceptive intent, without complying with the LAM criteria. Therefore the primary stage health care personnel, and through it the delivering women, should be educated about starting and maintaining successful breastfeeding, lactation before and after delivery, and the contraceptive use of breastfeeding.

\section{Funding: No funding sources}

Conflict of interest: None declared

Ethical approval: The study was approved by the Institutional Ethics Committee

\section{REFERENCES}

1. A Natural Contraceptive. Network, 1990;12:8.

2. Tommaselli GA, Guida M, Palomba S, Barbato M, Nappi C. Using complete breastfeeding and lactational amenorrhea as birth spacing methods. Contraception. 2000;61:253-7.

3. Taylor HW, Vazquez- Geffroy M, Samuels SJ, Steven JS, Taylor DM. Continuously recorded suckling behaviour and its effect on lactational amenorrhoea. J Biosoc Sci. 1999;31:289-90.

4. Valdes V, Labbok MH, Pugin E, Perez A. The efficacy of the lactational amenorrhea method (LAM) among working women. Contraception 2000;62:217-19.

5. Kennedy KI, Labbok MH, Van Look PF. Lactational amenorrhea method for family planning. Int J Gynecol \& Obstet. 1996;54:55-7.

6. Speroff L, Mishell DR. The postpartum visit: it's time for a change in order to optimally initiate contraception. Contraception. 2008;78(2):90-8.

7. World Health Organization. Department of Reproductive Health and Research. Medical Eligibility Criteria for Contraceptive Use $3^{\text {rd }}$ ed. Geneva: WHO; 2004.

8. Leung Ak, Sauve RS. Breast is best for babies. J Natl Med Assoc 2005; 97:1010-9.

9. McNeilly AS. Lactation and fertility. J Mammary Gland Biol Neoplasia 1997;2:92.

10. Vural B, Vural F, Erk A, Karabacak O. Knowledge on lactational amerorrhoea and contraception in Kocaeli, Turkey. East Afr Med J. 1999;76:385-9. 
11. Lopez-Martinez MG, Romero-Gutierrez G, PoncePonce De Leon AL. Acceptance of lactational amenorrhoea for family planning after postpartum counseling. Eur J Contracept Reprod Health Care. 2006;11:297-301.

12. Vikhlyaeva E, Nikolaeva E, Brandrup-Lukanov A. Contraceptive use and family planning after labor in the European part of the Russian Federation: 2year monitoring. Eur J Contracept Reprod Health Care 2001;6:219-26.

13. Little P, Griffin S, Dickson N, Sadler C. Unwanted pregnancy and contraceptive knowledge: identifying vulnerable groups from a randomized controlled trial of educational interventions. J Fam Pract 2001;18:449-53.

14. Miller VL, Laken MA, Ager J, Essenmacher L. Contraceptive decision making among Medicaideligible women. J Community Health. 2000;25:47380 .

15. Hiller JE, Griffith E. Education for contraceptive use by women after childbirth. Cochrane Database Syst Rev. 2000;2:1-3.

16. Kantner A, Westley SB. Family planning for new mothers in the Philippinnes. Asia Pac Pop Policy 1998;47:1-4.

17. Kennedy KI, Rivare R, McNelly AS. Consensus statement on the use of breastfeeding as a family planning method. Contraception. 1989;39:477-86.
18. American Academy of Pediatrics. Workgroup on Breastfeeding: breastfeeding and the use of human milk Pediatrics 1997;100:1035-9.

19. Ravera M, Ravera C, Reggiori A, Cocozza E, Cianta F, Riccioni G, et al. A study of breastfeeding and the return of menses in Hoima District. Uganda East Africa Med J. 1995;72(3):147-59.

20. Susu B, Ransjo-Arvidson AB, Chintu K, Sandstorm K, Christensson K. Family planning practice before and after child birth in Lusaka, Zambia. East Af Med J. 1996;73(11):708-13.

21. Diaz S. Determinants of Lactational Amenorrhea. Int of Gynecol \& Obstet. 1989;1:83-9.

22. Shawky S, Abalkhail AB. Maternal factors associated with the duration of breasfeeding in Jeddah. Saudi Arabia. Paediatr Perinat Epidemiol 2003;17:91-6.

23. Turkey Demographic and Health Survey. Hacettepe University Institute of Population Studies, Ministry of Health, Turkey Demographic and Health Survey. 2008 Summary Report Ankara, 2009.

24. Khella AK, Fahim HI, Issa AH, Sokal DC, Gadalla MA. Lactational amenorrhoea as a method of family planning in Egypt. Contraception 2004;69:317- 22.

Cite this article as: Pirincci E, Taşdemir R, Oguzoncul AF. Knowledge of lactational amenorrhea as a contraceptive method among mothers of infants aged 06 months in a district, Eastern Turkey. Int J Community Med Public Health 2016;3:1363-70. 